\title{
Censorship, or the Wisdom of the Simian Trinity
}

Dr Rupendra Guha-Majumdar ${ }^{\dagger}$

\section{Abstract}

Since early civilisation, mankind has revealed the dual tendency, after acquiring the myriad skills of articulation, to control, repress, edit in subjective and objective terms, that which is naturally expressed by the human mind and body in the varied contexts of myth, history and contemporary, socio-political consciousness. This urge has been simultaneously complemented by that of recording, composing and theorising the paradoxes of censorship through art, literature, philosophy and other pulses of meditation in cultures stretching across the world from the Orient to the Occident, with the implicit hope of counterpointing the gravitational pulls of mutability in mankind's natural striving to ascend to the infinite beyond.

Keywords: Civilisation, memory, freedom, censor, repress, intolerance, arête, humanism, transgression, mystic

\footnotetext{
${ }^{\dagger}$ Associate Professor (Retired), Department of English, University of Delhi Email: rupendraguha@gmail.com

(C) 2018 Guha-Majumdar. This is an Open Access article distributed under the terms of the Creative Commons Attribution License (http://creativecommons.org/licenses/by/2.0), which permits unrestricted use, distribution, and reproduction in any medium, provided the original work is properly cited.
} 


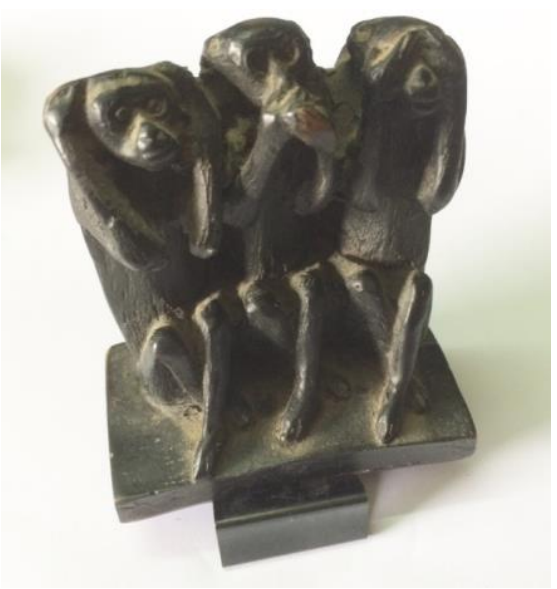

\section{Introduction}

Every civilisation which exists-or had once existed-tends to engender the languages by which it expresses its own organic identity as long as it can. Moreover, every language, worth its linguistic salt, consolidates, so to speak, the tensions between its potential and kinetic energies in order to vindicate itself. Memory, experience, and visions of survival in the phenomenal world strive for manifestation in different degrees through the vindication or negation of speech, of words, of the narrative voice telling its myriad, chaotic stories with or without the sanction of freedom. One can look into some of the factors which allow speech to grow or suffer extinction, literally or metaphorically, overages in a world where, as Heraclitus the Greek philosopher once observed, life is always in a state of flux.

Languages are volatile in nature. Their inner impulse is to move and to grow, like seeds, though often they can be snuffed out without sufficient reason by sandstorms across dark horizons. Like civilisations, languages follow the trajectories of the Centrifugal and the Centripetal, that is, the forces which move outwards from the centre to the world without, and those which prefer to return to the centre of the vortex of the soul to look inwards into unsolicited and buried secrets of the tribe. The latent become dynamic and vice versa. Languages have a tendency of converting nouns (representing stable, given, pre-determined values) into (kinetic) verbs and adjectives which go beyond in qualifying meaning; or names and roles into abstract qualities and principles in a natural process of naming and codification, though quite often such drastic projections may not do justice to the original.

For example, we say, what's in a name? May be, a lot! There is a wide gap between the names 'Machiavelli' or 'Seneca' and their respective adjectives in $16^{\text {th }}$ century England. Machiavelli, the man and minister in a medieval Italian court, was nowhere near the devilish figure that the adjective of his name, translated into English, made him out to be on the Elizabethan stage. The word 'Machiavellian' was often like a bomb which just had to be dropped in the right place and time on the English stage, for everyone to run for sanctuary. It was the same story with Roman 'Seneca.' Both these words were devastating in their histrionic, Elizabethan, adjectival transformations representing intrigue, unscrupulousness, opportunism and violent bloodshed. Particular atoms of truth were inflated into large molecular structures to convey the chess-games of power to a bewildered and sensational world.

Today we are concerned with another Italian/Latin noun from the $16^{\text {th }}$ century, 'CENSOR' originally meaning an official formally appointed to take the 'CENSUS' of a city and also to supervise public morality. Its Latin verb, 'CENSERE', means to assess; and translated into English in the same age, it conveyed the sense of "officious judge of morals and conduct." The Roman CENSOR is also associated with a sense of the severity of judgement by a rigid moralist who adopts the guise of a CENSURER. Gradually the word, in its essential connotation in English, adopted the significance of a state-geared agency that was basically repressive of published material or works of art that could be classified as subversive.

\section{Discussion}

The idea of Censorship of public speech or artistic forms of individual expression in painting and, later, film has a long history going far beyond the $16^{\text {th }}$ century. However, in different degrees, it is as old as civilisation 
all over the world-that of Egypt, Greece, Rome, China, Japan, India, and others. Strangely enough, it is a double-edged idea. The slogan 'freedom of speech' is almost an oxymoron as no community on earth, bound by social laws, can afford or allow absolute freedom of speech or action while measuring the polarities of good and evil, right and wrong, colonial and post-colonial. On the one hand, the demand for such freedom is natural; but on the other hand, Censorship finds justification in the fact that freedom of speech even in a democratic state is a relative concept and not an absolute one; freedom is conceded conditionally; a quota of so much freedom for so much speech!

It is a concept that emerges from an acknowledged tradition of restraint, discipline, and law. It implies the existence and nurturing, stage by stage of an evolutionary yet organised process of society that demands careful preservation and respect of its resources, as well as the unhampered growth of its potential day by day. The problem starts when this kind of reasoning is pushed gradually to a neurotic extreme when the necessity to check 'difference' under the charge of selfdestructivity, becomes more and more acute; when the freedom of one viewpoint of an ethnic group is seen to complicate, subvert, dilute the genesis of another group or interest in the same land. This could lead to absolute intolerance. It could lead to the gas chambers of Auschwitcz during the Holocaust. There, Censorship reaches its limits based on an arbitrary view of Man.

The ideas of restraint, not submitting to temptation, sustaining rational limits to human experience-are conditions of social behaviour from ancient times in almost all cultures and religions. Moreover, the big question becomes: who does the restraining? Who has the right to check, restrain, dictate the norms of that which is likely to spill beyond limits-can only be answered by a paradox. It is a paradox that surfaces again and again in different forms. We find it in the
Upanishads: "Dharma rakhshati rakhshita!" Protect Dharma; and Dharma will protect you.

In pre-Christian times, the Greeks paradoxically advocated on the one side the notion of ARETE (heroic excellence) and on the other, that of SOPHROSYNE (nothing in excess). The two concepts, working in tandem, ensured an expedient checking or censoring of the self. In the concluding book of Homer's The Iliad, even the barbaric Myrmidion of Greece, Achilles, weeps on the side when King Priam of Troy begs him on bended knee to return the corpse of his son, Hector, killed by the latter a day earlier:

"Revere the gods, Achilles! Pity me in my own right,

\section{Remember your own fatherl}

I have endured what no one on earth has ever done before-

I put to my lips the hands of the man who killed my son."

Those words stirred within Achilles a deep desire

To grieve for his own father. Taking the old man's hand

He gently moved him back. And overpowered by memory

Both men gave way to grief." (Homer, The Iliad, tr. E.V.Rieu, Book 24, II.588595)

Thus Achilles is checked and briefly mellowed by his understanding of a father's grief for his dead warrior son through an unprecedented humanist discourse that he, the conqueror, finally acknowledges as viable and true.

Likewise, Aeschylus, in his Attic trilogy The Oresteia (458 BC) inverts, through the agency of goddess Athena, the entire system of jurisprudence in Athens by shifting the powers of judgement over all crimes, from the chthonic agencies of vengeance, the Furies/Erinyes, to the Athenian citizens themselves in a new formulation of necessary democracy, the Aeropagus; and thereby checks and qualifies the mindless course of 
blood revenge that was continuing over generations of unmitigated and barbaric violence. Here divine censorship achieves, in the terms of Greek tragedy, a cathartic significance for all concerned. Here gods take the trouble to check themselves in a language of humanism.

The Christian world, seen through the Old and New Testaments, in various degrees, exercises its own standards of censorship regarding the restitution of a moral order amongst its denizens on planet earth. We witness the Flood; then Sodom and Gomorrah-the excessive expressions of pride, avarice, and hedonism are checked and punished. We discover a unique instance in The Book of Job (which Lord Alfred Tennyson called, "the greatest poem of ancient and modern times"), where the protagonist is hypothetically censored by a Hebraic God, his worldly happiness cut down temporarily, to prove a point to Satan-the fact that Job's intrinsic piety is not dependent on his material happiness but on his unconditional commitment to the Lord who has, ironically, no doubt at all about Job's integrity. This is perhaps the only example in the history of censorship in which the person under scrutiny for crossing his limits has not ever really done so or is likely to, but nonetheless, is acutely 'censored' like a dire sinner for the possibility of transgression by the supreme censor who is himself, along with his dumbfounded protégé, taken for a circuitous ride by the supreme trickster, the Devil! The Morality Play tradition in medieval England, exemplified by the play Everyman, continues in this vein of Hide and Seek. That is, of the Soul. The Morality Play had to soon withhold its remonstrating, allegorical finger, as the powerful secular drama and poetry of the Elizabethan Renaissance, reinforced with a fresh vocabulary and rhythm gathered from a translated pre-Christian, Greco-Roman tradition, and led by writers like Sidney, Spenser, Marlowe, and Shakespeare, took over.
But when at the end of the $16^{\text {th }}$ century we confront Marlowe's Doctor Faustus, we realise that the idea and act of censoring a moral overreacher, like the learned Doctor, of his status and learning, for the crime of transgressing every single law in the book, including that of wanting to marry someone else's stunner of a wife, Helen of Troy-such censoring may not be only imposed from above but can be executed also from within the man in poetical and existential terms. And thereby lies the problem of taking the phenomenon of Censorship for granted as an overtly anxious, imposed structure of moral propriety, a system with carefully constructed entrances and exits and benevolent fathers standing by, ready to take back with open arms their prodigal sons. Surely, Faustus is not finally excited about being one of the latter. $\mathrm{He}$ is the biggest Prodigal that ever was minus the joyous nostos or homecoming. His selfawareness and angst of having burnt his boats go far beyond the limits of conventional Christian censorship of right and wrong; it is neither God nor the Devil, but he himself who, in his absolute isolation, asks:

"Why wert thou not a creature wanting soul?

hast?"

Or why is this immortal that thou

(Christopher Marlowe, Doctor Faustus, Act V, Sc. ii, 173-174)

I will conclude my indulgent, far-flung observations with an Oriental image, that of the three wise or mystic monkeys who are supposed to be hailing from the interlinked Buddhist heritage of India, China, and Japan. I think they have the last word on CENSORSHIP without making an officious scene about it. In Japanese folklore we see the following: Mizaru covering his eyes says: See no evil! Kikazam, covering his ears, says: hear no evil! Iwazaru, covering his mouth, says: speak no evil! The source of this visual maxim which has found a central place all over the worldincluding Mahatma Gandhi's Sabarmati Ashram in Ahmedabad, India-is attributed to a $17^{\text {th }}$ century carving of a simian trinity over a 
door of the famous Toshi-gu shrine in Nikko, Japan, carved by Hidari Jingoro who is supposed to have incorporated Confucius's Code of Conduct, employing the wisdom of the three monkeys as a means of portraying the life-cycle of man:

"Look not at what is contrary to propriety; listen not to what is contrary to propriety; speak not what is contrary to propriety" together they suggest the Middle Path of Mahayana Buddhism, the focused strictness that the self must undergo in its own worldview of self-censorship to the very end.

And even if Doctor Faustus had consulted the three wise monkeys during his hedonistic, 24year, self-aggrandizing jaunt around the world, he could not have denied that he was fully responsible for practicing "more than heavenly power permits", in short, for overreaching!

And later on we can look into the relatively more contemporary traumas of Censorship, than the ones discussed above, regarding 19th and $20^{\text {th }}$ century works and, often, their respective films-like Mark Twain's Huckleberry Finn (1884), Eugene O'Neill's Desire under the Elms (1924), D.H. Lawrence's
Lady Chatterley's Lover (1928), Charlie Chaplin's film Monsieur Verdoux (1947), John Osborne's Look Back in Anger (1956), and many more. All of them pass through trials of fire before rising to the occasion and redeeming themselves in the eyes of the humble reader. It is a fascinating but murky discourse-closing the eyes, the ears, the mouth of the sentient mind ... and expecting, strangely enough, that all's right with the world!

\section{References}

The Upanishads

Homer, The lliad (760 BC)

The Book of Job, The Tanakh (Hebrew Bible)

Gautama Buddha, The Dhammapada (6th cent $\mathrm{BC}$ ?)

Heraclitus, Fragments (late 6th cent BC? )

Confucius, Code of Conduct (6th cent BC ?)

Aeschylus ,The Oresteia (458 BC)

Seneca, Ten Tragedies (20 AD; 1581)

Everyman (1510), (Anonymous author)

Machiavelli, The Prince (1532) 